\title{
7 Haziran ve 1 Kasım 2015 Genel Seçimleri Bağlamında Cumhuriyet Halk Partisine Yönelik Bir Karşılaştırma ${ }^{1}{ }^{*}$
}

\author{
Ahmet Hikmet ZABUN \\ Dr., Kahramanmaraş Sütçü İmam Üniversitesi, Rektörlük \\ zabun@ksu.edu.tr \\ Orcid ID: https://orcid.org/0000-0003-3783-8168
}

\begin{abstract}
Öz
Türkiye'de 2015 yılında yapılan 7 Haziran 2015 genel seçimleri, hükümetin kurulamaması nedeniyle 1 Kasım 2015 tarihinde tekrarlanmıştır. Muhalefet partilerinden Cumhuriyet Halk Partisi (CHP), Milliyetçi Hareket Partisi (MHP) ve Halkların Demokratik Partisi (HDP) aldıkları oy oranı ve kazandıkları milletvekili sayılarıyla koalisyon hükümeti çıkartabilecek bir parlamento dağılımı ortaya çıkarmışlardır. Koalisyon görüşmelerinin olumlu sonuçlanmaması ve hükümet kurulamayacağı kanaati ile Cumhurbaşkanı tarafından seçimlerin tekrarlanmasına karar verilmiştir. 1 Kasım 2015 tarihinde tekrarlanan genel seçimlerde önceki seçime göre oy kaybını telafi eden AK Parti tek başına iktidar olanağını elde etmiştir. MHP ve HDP önemli oranlarda oy kaybına rağmen Türkiye Büyük Millet Meclisi (TBMM)'ne girmeyi başarmıştır. Çalışmaya konu edilen Cumhuriyet Halk Partisi (CHP)'nde ise tekrarlanan genel seçimlerde oransal bir artışın sağlanamadığı görülmüştür. 7 Haziran 2015 genel seçimlerinde etkili bir kampanya yürüten ve koalisyon görüşmelerine de katılan CHP'nin 1 Kasım 2015 genel seçim sürecindeki kampanya stratejisi, kullandığ mesaj ve mecraların incelenmesi ve karşılaştırmalar yapılması siyasal iletişim bağlamında önemli veriler sunacaktır.
\end{abstract}

Anahtar Kelimeler: CHP, Seçim, Medya, Siyasal Partiler.

\footnotetext{
${ }^{1}$ Makale Geliş/Kabul Tarihi: 02.10.2019 / 15.04.2020

* Bu makale Prof. Dr. Selma KARATEPE danışmanlığında yürütülen "Haziran ve Kasım 2015 Genel Seçim Kampanyalarının AK PARTİ, CHP, MHP ve HDP Üzerinden Karşılaştırmalı Bir Analizi” adlı doktora tezinden özetlenerek türetilmiştir.

Künye Bilgisi: Zabun, A.H.. (2020). 7 Haziran ve 1 Kasım 2015 Genel Seçimleri Bağlamında Cumhuriyet Halk Partisine Yönelik Bir Karşılaştırma. Kahramanmaraş Sütçü İmam Üniversitesi Sosyal Bilimler Dergisi, 17 (1), 519-530. DOI: 10.33437/ksusbd.628235
} 


\title{
A Comparison Into Republican People's Party (CHP) In Terms of June 7th and November 1st, 2015 General Elections
}

\begin{abstract}
General elections made on 7th June 2015 in Turkey was repeated on 1st November, 2015 as the government was not able to be formed. The opposition parties, Republican People's Party (CHP), Nationalist Movement Party (MHP) and Peoples' Democratic Party (HDP) had a parliamentary distribution that would be able to form a coalition government with the numbers of deputy and the rate they had. Because the coalition negotiations did not result in positively and having the idea that a government would not be able be formed, it was decided to repeat the elections by the President. Compensating the former loss of votes in the repeated elections made on 1st November, 2015, Justice and Development Party (AK Parti) was able to get the opportunity to form the government alone. Despite their significant losses of vote, MHP and HDP were able to enter Turkish Grand National Assembly (TBMM). As for CHP, which will be studied in the current research, it was seen that it was not able to have a proportional increase in the general elections. The investigation of the campaign strategy of CHP, carrying out an active campaign in the general election held on June7, 2015 and also involving in the coalition negotiations, in the general election proces on November 1, 2015, the messages and places it uses and making comparisons would give significant data in the context of political communication.
\end{abstract}

Keywords: CHP, Election, Media, Political Parties.

\section{Giriş}

2015 yılında Türkiye'de beş ay süre arayla iki genel seçim yapılmıştır. 7 Haziran 2015 tarihinde yapılan genel seçimlerde 13 yıllık tek başına iktidarı sonrası AK Parti seçimi birinci olarak tamamlamış ancak tek başına iktidar olanağını kaybetmiştir. 7 Haziran 2015 genel seçimlerinde, 2011 Genel Seçimlerinde bağımsız adaylık yoluyla Türkiye Büyük Millet Meclisi (TBMM)'ne girerek grup kuran parlamenterler Haziran 2015 Genel Seçimlerine Halkların Demokratik Partisi (HDP) çatısı altında girmiş ve yüzde 13'lük oy oranı ile TBMM'ye girmeyi başarmıştır. 2011 yılında yapılan genel seçimlerde TBMM'ye giren Milliyetçi Hareket Partisi (MHP) ve CHP de Haziran 2015'te yapılan genel seçimlerde Meclis’te temsil olanağını elde etmiştir. 
A.H.Zabun 7 Haziran ve 1 Kasım 2015 Genel Secimleri Bağlamında...

Hükümeti kurmakla görevlendirilen AK Parti’nin CHP ile yürüttüğü koalisyon görüşmelerinin olumlu sonuçlanamaması ve bir koalisyon hükümeti kurulamaması nedeniyle seçimlerin yenilenmesine karar verilmiş ve $1 \mathrm{Kasım}$ 2015 tarihinde genel seçimler tekrarlanmıştır. Tekrarlanan genel seçimlerde yaklaşık yüzde onluk bir artış sağlayan AK Parti tek başına hükümet kuracak çoğunluğu elde etmiştir. 7 Haziran 2015 Genel Seçimlerinde seçmen kitlelerine şimdiye kadar yapılanlar/bundan sonra yapılacaklar şeklinde uzun metinlerle hitap eden Ak Parti'nin 1 Kasım 2015 Genel Seçimlerinde strateji değiştirdiği görülmüştür. Asgari ücretin $1300 \mathrm{TL}$ olacağı, taşeron işçilere kadro verileceği gibi kısa ve çoğunluğu ekonomik içerikli mesajların oluşan farklılıkta etkili olduğu ifade edilebilir. Tekrarlanan genel seçimlerde CHP'nin oylarında oransal bir farklılığın oluşmadığı görülmüştür. Bu sonuçta reklam sayılarının ve içeriklerinin azaltılması ya da değiştirilmesinin etkili olduğu ifade edilebilir. İncelenen gazeteler bağlamında reklam sayılarının 87 'den 21 'e düştügünü ve üç içerikle kampanya organize edildiğini belirtmek gerekmektedir. MHP ve HDP ise milletvekili sayısı ve oy kaybı ile TBMM'de temsil imkânı elde edebilmiştir.

CHP'nin koalisyon hükümeti ortağı olma olanağını yakaladığı görüşmelerin olumsuz sonuçlanması, tekrarlanan genel seçimlerde ise oransal anlamda kayda değer bir artış sağlayamaması her iki genel seçimde yürüttüğü kampanyanın incelenmesini gerektirmektedir. Bu bağlamda yapılacak bir karşılaştırma seçim kampanyasında kullanılan mesaj ve mecraların oy oranlarına yönelik etkisi ve kampanya stratejilerine yönelik değerlendirme olanağı sunmaktadır. $\mathrm{Bu}$ çalışmada CHP'nin seçim kampanyasına esas olan reklamları ve kullanılan basılı medya organları incelenmiş ve karşılaştırmalar betimsel analizle ortaya konulmuştur. Kampanyada kullanılan mesajlar; ekonomi, iç politika, dış politika, eğitim, kültür-sanat temaları (Karlı, 2009) ve diğer başlığı altında tablolaştırılarak karşılaştırmalara olanak sağlanmıştır. Çalışmada; kitap, makale, internet vb. yazılı kaynaklardan yararlanılmış, farklı toplumsal kesimlere hitap eden Hürriyet, Sabah, Cumhuriyet, Sözcü, Evrensel, YeniŞafak ve Yeniçağ gazetelerinde CHP reklamları taranmış, bilgi işleme aracı olarak ise nitel bilgi işleme yöntemi kullanılmıştır.

\section{Cumhuriyet Halk Partisi (CHP)'nin Tarihçesi}

CHP, Cumhuriyet tarihinin en eski partisi olup kuruluşundan sonraki yıllarda da bünyesinden birçok parti çıkarmıştır. Parti, Milli Mücadele döneminde mücadelenin kazanılmasına katkı sağlayan Müdafaa-i Hukuk Cemiyetleri temeli ve örgütlerinden yararlanılarak Mustafa Kemal Atatürk'ün Anadolu-Rumeli Müdafaa-i Hukuk Cemiyetlerinin partiye dönüştürmesi dolayısıyla da önem taşımaktadır. Parti'nin kurulmasına ilişkin ilk açıklama 6 Aralık 1922 yılında Atatürk tarafindan yapılmış ve 'Halk Fırkası' adı bu açıklamada yer almıştır (Uyar, 2012: 65). CHP'nin ilk kurultayı Sivas Kongresi olarak ifade edilmektedir. 
Illk kez bu kongrede yasama ve yürütmeye yönelik kararlar ülkenin çeşitli bölgelerini temsil eden üyeler tarafından alınarak devlet kurma girişimi başlatılmıştır. Devlet kuran parti olarak CHP'nin bu kongrede filizlenmeye başladığı ifade edilmekte, Atatürk'ün de CHP'nin temelinde Anadolu ihtilalinin yattığını ifade ederek Sivas Kongresi'ne dikkat çektiği belirtilmektedir (Bila, 2008:14). "Halk Firkası" olarak kurulan partinin adı 1924 yılında "Cumhuriyet Halk Fırkası" 1935 yılında da "Cumhuriyet Halk Partisi" olarak değiştirilmiştir (Aybek, 2009: 8). Sivas Kongresi ile başlayan, TBMM'nin kurulmasıyla devam eden ve Cumhuriyetin ilanına uzanan süreç ya da dönem CHP'nin kuruluş çalışmalarının da devam ettiği bir zaman dilimi olarak ifade edilebilir.

1923 seçimleri sonrası yenilenen Meclis, CHP'nin kuruluş sürecinin son basamağ1 olarak ifade edilmektedir. Yeni Meclis'in Müdafaa-i Hukuk milletvekilleri seçimlerden önce hazırlanan 9 Umde esas olmak üzere Halk Fırkası Nizamnamesi'ni yaparak 9 Eylül 1923 günü kabul etmişler ve 11 Eylül 1923 tarihli İçişleri Bakanlığına verilen dilekçe ile de "Halk Fırkası"nın resmi kuruluşunu gerçekleştirmişlerdir. Fırkanın genel başkanlığına Mustafa Kemal Atatürk, genel başkan vekilliğine İsmet İnönü ve genel sekreterliğine de Kütahya Milletvekili Recep Peker seçilerek yönetim kurulu oluşturulmuştur (Bila, 2008:36-37).

Yukarıda da ifade edildiği üzere Fırka, 1935 yılında Cumhuriyet Halk Partisi adını almış ve 1950 yılına kadar tek parti dönemi olarak adlandırılan dönemde ülke yönetimini sürdürmüştür. 1923-1950 yılları arasındaki 27 yıllık tek parti yönetimi boyunca üç kez çok partili hayat denemesi gerçekleştirilmiş fakat bunlardan sadece sonuncusu başarılı olabilmiştir (Uyar, 2012: 81). İlk çok partili deneme 17 Kasım 1924'te İçişleri Bakanlığı'na verilen dilekçeyle kurulan Terakkiperver Cumhuriyet Fırkası (TCF)'dır. Halk Fırkası içerisinde Hükümeti eleştirenlerin istifasının ardından muhaliflerce kurulan partinin kamuoyundan destek görmesi, örgütlenme çabaları ve milletvekili sayısının artmasıyla ilgi odağı haline gelmesi Halk Fırkasını da telaşlandırmıştır. TCF'nın kurulması sonrasında yaşanan gelişmeler ve Doğu'da Şeyh Sait isyanının başlamasıyla süreç sert önlemleri içeren Takrir-i Sükun Kanununun çıkarılmasına uzanmıştır. İstiklal Mahkemelerinin aldıkları kararlar doğrultusunda Bakanlar Kurulu 3 Haziran 1925'te Takrir-i Sükun Kanununa dayanarak TCF'nın kapatılmasına karar verir. TCF'nın kapatılmasından beş yıl sonra yönetim sistemine Batı'dan gelen eleştiriler doğrultusunda Atatürk'ün teşvikiyle 12 Ağustos 1930 tarihinde Fethi Okyar başkanlığında Serbest Cumhuriyet Fırkası (SCF) kurulur. SCF'nın da kısa zamanda ilgi odağı olması partilerin karşı karşıya gelmesi ve ortaya çıkan gerginlikler Fethi Bey'in partiyi fesih kararı ile son bulmuş ve 17 Kasım 1930 tarihinde SCF denemesi de sona ermiştir (Öz, 1992: 88-108). 
A.H.Zabun 7 Haziran ve 1 Kasım 2015 Genel Seçimleri Bağlamında...

1931 yllından itibaren gücünü sağlamlaştıran CHP muhalefeti parti içi muhalefetle sınırlandırmıştır. 1931 yılında yapılan seçimlerin ardından parti doktrininin ilkeleri tartışlarak programa yazılmıştır (Ayata, 2010: 68-69). Cumhuriyet Halk Partisi 1927 yılında Cumhuriyetçilik, Halkçılık, Milliyetçilik ve Laiklik ilkelerini CHP'nin dört temel ilkesi olarak benimsemiş, 1935 y1lında bu ilkelere Laiklik ve Devrimcilik ilkelerini eklemiştir. CHP'yi simgeleyen bu ilkeler partinin de amblemi olan 6 ok olarak da kullanılmıştır (Aybek, 2009: 8).

CHP'nin 1931 tarihli programında bir dereceli seçimin toplumun belli bir demokratik olgunluğa erişmesinden sonra uygulanabilecek bir ideal bir hedef olduğunun algılandığı ifade edilmektedir. Bu doğrultuda Tek parti döneminde yapılan iki dereceli seçimlerin milletvekili aday listelerinin halk tarafından onaylanması anlamında olduğu belirtilmektedir. İki dereceli seçimler dolaylı, gerçek rakip adaylara şans tanımayan tasdik niteliği taşıyan seçimler olarak gerçekleşmiştir. 1946 yılına kadar bu şekilde yapılan seçimler, 1946 yılında ilk kez tek dereceli usulle yapılmış, seçimlerin açık oy gizli tasnifle yapılması nedeniyle sağlıklı bir sonuç ortaya konulamamıştır. 1950 seçimleri öncesinde tek dereceli seçim usulü, gizli oy, açık tasnif ve yargı güvencesi ile yapılan seçimlerde CHP çoğunluğu kaybederek 27 ylllık tek parti dönemi kapanmıştır (Uyar, 2012: 258-259).

1950'de seçimlerini kaybeden CHP, 1954 yılında yapılan seçimlerde oyların yüzde 34,8'ini, Meclisteki sandalyelerin de 31 tanesini alarak bir seçim yenilgisi daha yaşamışlardır. 1957 seçimlerinde CHP yüzde 40,6 alarak oylarını yükseltmesine ve muhalefet partileriyle birlikte DP'den daha fazla oy almalarına rağmen çoğunluk sisteminde kaynaklı olarak Meclis çoğunluğunu elde edememişlerdir. 27 Mayıs 1960 askeri müdahalesinin ardından yapılan seçimlerde CHP oyların yüzde 36,7'sini almış ancak çoğunluk partisi olamadığından koalisyon kurmak zorunda kalmıştır. 1961-1965 yılları arasında kurulan dört hükümetin üçünde CHP yer almıştır. 1965 yılında yapılan seçimlerde yüzde 28,7 oy alan ve iktidarı Adalet Partisine bırakan CHP, 1969 seçimlerinde yüzde 27,4 oy alarak muhalefette kalmaya devam etmiştir. 12 Mart 1971 y1lında verilen muhtıradan sonra kurulan Nihat Erim hükümetini İnönü'nün desteklemesiyle İsmet İnönü ile CHP Genel Sekreteri Bülent Ecevit arasında ihtilaf doğmuş, parti içi mücadele sonrası yapılan 5 Mayıs 1972 tarihli kurultay sonrasında 14 Mayıs 1972'de Ecevit CHP'nin genel başkanı seçilmiştir (Ayata, 2010: 78-86).

Parti lideri CHP Genel Başkanı olarak ilk sınavını milletvekili genel seçimlerinde veren Ecevit 14 Ekim 1973'te yapılan seçimlerde başarı sağlayarak 185 milletvekili çıkarmıştır. Meclis dağılımı salt çoğunluğu sağlayamayan bir yapıda oluştuğundan koalisyon hükümetleri dönemi başlamış ve Bülent Ecevit liderliğindeki CHP ile Necmettin Erbakan liderliğindeki Milli Selamet Partisi ile 
hükümet kurulmuştur. 1974 Kıbrıs Barış Harekatı sonrasında iç ve dış siyasetteki gelişmeler neticesinde ortaya çıan anlaşmazlık nedeniyle 7,5 ay süren ortaklık sonlandırılarak 18 Eylül 1974 tarihinde Bülent Ecevit hükümetin istifasını vermiştir. Koalisyonun bozulması sonucunda parti içinde başlayan tartışmalar sonrasında 'demokratik sol düşünce' konusunda forumlar düzenlenmiş 22 ve 23'üncü kurultaylarda da tartışmalar bu kavram çerçevesinde devam ettirilmiştir. 1976 y1l sonunda kabul edilen programa "Cumhuriyet Halk Partisi Demokratik Sol Bir Siyasal Partidir" açıklaması konularak ayrıntılı ve kapsamlı bir program ve yeni bir kadroyla 1977 seçimlerine girilmiştir. 5 Haziran 1977 yılında yapılan seçimlerde CHP 213 milletvekili ile birinci parti olmuştur. Hükümeti kurmakla görevlendirilen Bülent Ecevit partiler arası uzlaşma sağlayamadığından azınlık hükümeti kurmuş ancak güvenoyu alamayarak yerini Süleyman Demirel başbakanlığında kurulan Milliyetçi Cephe hükümetine bırakmıştır. 1978 y1lı başında yeniden hükümet kurma olanağı elde eden Ecevit TBMM'de salt çoğunluğu sağlamak için 11 bağımsız milletvekili ile anlaşmış ve Aralık 1979 yılına kadar devam edecek hükümeti kurmuştur. Bu koalisyon da hükümet içinde baş gösteren uyumsuzluklar ve ekonomik sıkıntıların giderek artması sonucu sona ermiştir. 12 Eylül 1980 Askeri müdahalesinin ardından 16 Ekim 1981 tarihinde diğer partilerle birlikte CHP'de kapatılmıştır. 1983'te yeni parti kurulmasına izin verilmesiyle birlikte CHP'liler Halkçı Parti ve Sosyal Demokrat Parti (SODEP) olarak ikiye bölünmüşler, Bülent Ecevit' in desteğiyle Demokratik Sol Parti'nin kurulmasının ardından parti sayısı üçe çıkmışır. Halkçı Parti ile SODEP'in birleşmesi sonucunda Sosyal Demokrat Halkçı Parti (SHP) kurulmuştur. 12 Eylül'de kapatılan partilerin yeniden kurulmasına imkan verilmesiyle birlikte 9 Eylül 1992'de ise CHP yeniden kurulmuştur. (Turan, 2000: 59-64). Sonraki süreçte birleşme çalışmaları başlatılmış, 1995 yılında SHP de CHP'ye katılmıştır.

\section{7 Haziran 2015 Seçimlerinde Ulusal Gazetelerde CHP Seçim Kampanyası}

7 Haziran 2015 Genel Seçimleri kapsamında seçimler öncesi gazetelerde CHP reklamları incelendiğinde Sabah Gazetesinde ve Yeni Şafak Gazetelerinde CHP reklamlarının yer almadığı görülmüştür. 7 Haziran seçimleri öncesinde CHP, 22 reklamla en fazla Cumhuriyet ve Hürriyet Gazetesinde yer almıştır. 18 reklam 7 Haziran seçimleri öncesinde Sözcü Gazetesine, 15 reklam Evrensel gazetesine verilmiş, 10 reklam ise Yeni Çağ Gazetesine verilmiştir. Farklı yayın organlarını kullanma bağlamında CHP'nin daha aktif bir kampanya süreci planladığı görülmektedir. Toplamda beş yayın organında 87 ilan yayınlanmışıır.

Reklamların başlıklarına bakıldığında 13 farklı reklam tasarımıyla karşılaşılmaktadır: "Öğretmen ve Öğrencisinin Sorunları Olmayan Bir Türkiye", "Yoksulu Olmayan Bir Türkiye", "Esnaf ve KOBİ'sinin Sorunları Olmayan Bir 
A.H.Zabun 7 Haziran ve 1 Kasım 2015 Genel Secimleri Bağlamında...

Türkiye”, “Asgari Ücretin Vergisi Olmayan Bir Türkiye”, "Kredi Borcu Çaresizliği Olmayan Bir Türkiye", "Emeklisinin Derdi Olmayan Bir Türkiye", "Kiraya Mahkûmiyeti Olmayan Bir Türkiye" ve "Çiftçisinin Sorunları Olmayan Bir Türkiye" başlıkları altında beyannamede sunulan vaatler reklamlarda da kısa kısa yer almaktadır.

Yukarıda ifade edilen başlıkların dışında seçmeni sandığa çağrıyı içeren CHP Genel Başkanı Kemal Kılıçdaroğlu sunumlu bir içerik, "Milletçe Alkışlıyoruz" başlıklı CHP'nin TV reklamlarına gönderme yapan bir reklam içeriği, yine "Milletçe Alkışlıyoruz" 'Neden Mi Alkışlıyoruz Ahmet Bey' slogan ve başlıklarından oluşan detaylı metnin yer aldığı bir içerik, "Merkez Türkiye" adı verilen ve Türkiye Ekonomik Yükseliş Projesi olarak ifade edilen proje reklamı ve gazetelerde yayınlanan reklamların tamamını içeren genel bir reklam metni gazetelerde yer almaktadır.

İlanların dağılımına bakıldığında; incelenen gazetelerde yayınlanan 87 ilanın 56'sı ekonomi, 21'i iç politika, 10'u diğer konu başlıkları altında yer almaktadır.

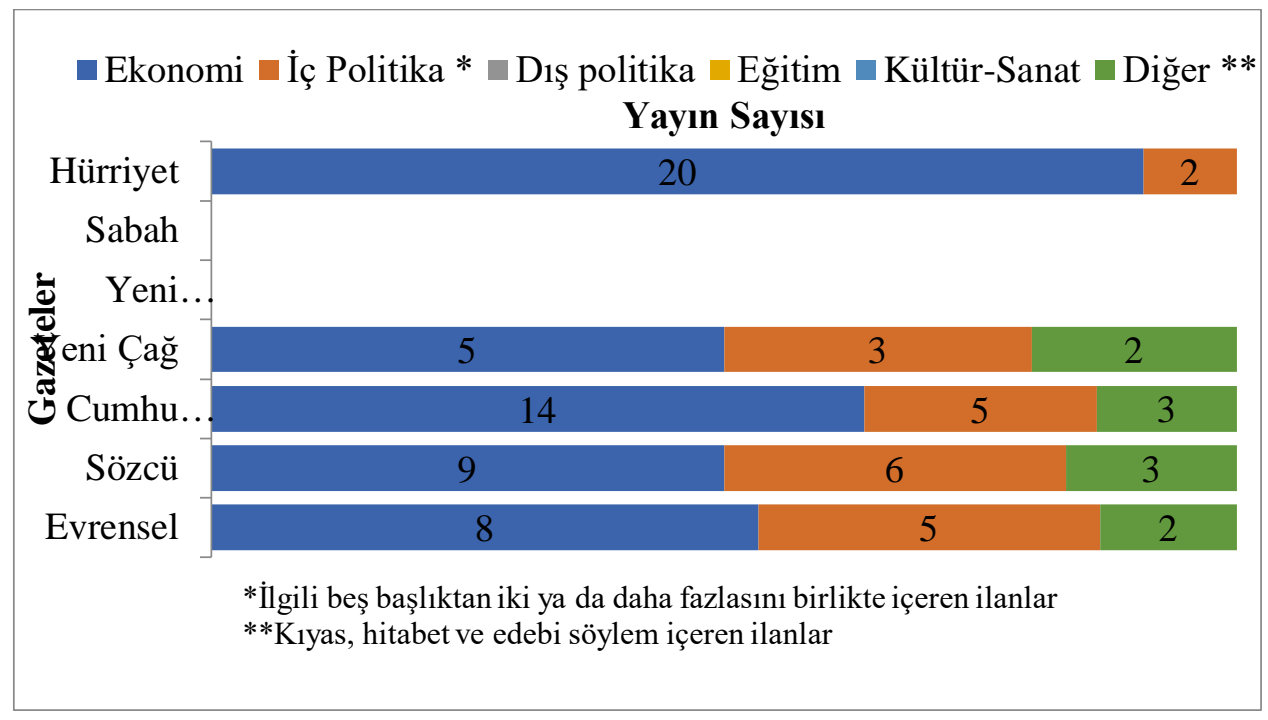

Şekil 1. İleti Konuları Başlığında Haziran 2015 Seçimlerinde CHP'nin Reklam Konu Dağılımı

İncelenen yayın organları bazında yayınlanan toplam ilanın \% 25'i Hürriyet, \% 25'i Cumhuriyet, \% 21'i Sözcü, \% 17'si Evrensel, \% 12'si ise Yeni Çă̆ gazetesinde yer almıştır. 


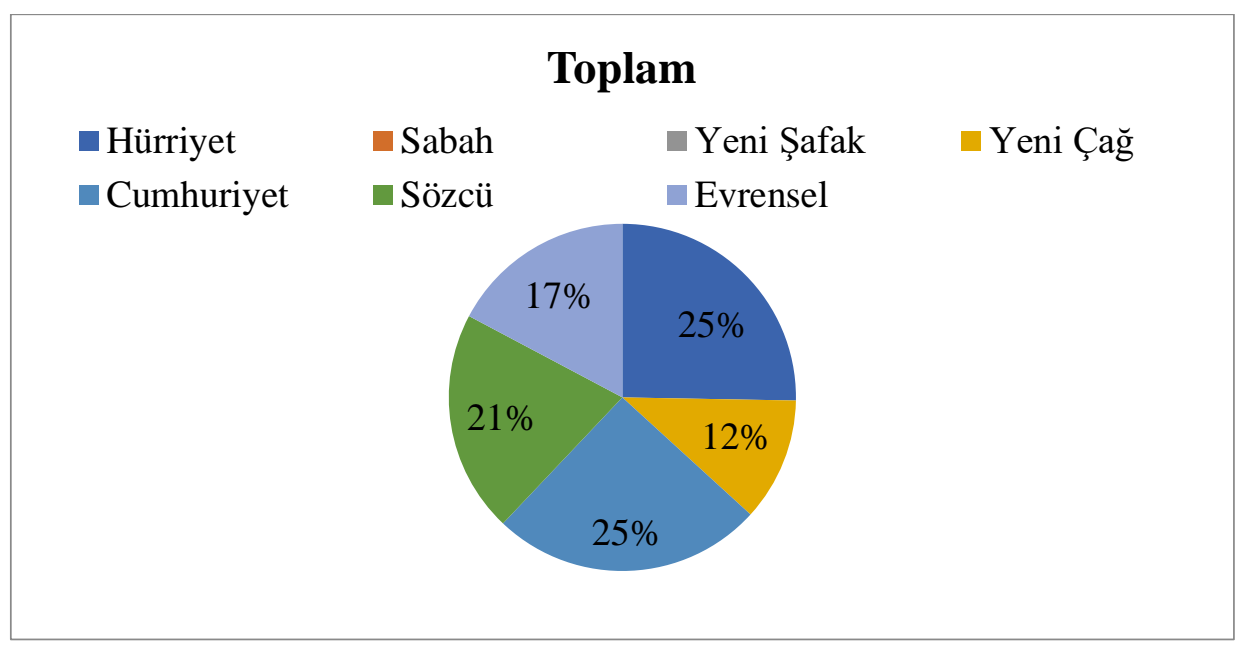

Şekil 2. Haziran 2015 Seçimlerinde CHP Reklamlarının Gazetelere Göre Dağglımı

7 Haziran 2015 Genel Seçim Sürecinde CHP'nin 13 farklı reklamının incelenen medyalar arasında 5 farklı yayın organında yer aldığı görülmüştür. Ağırlıklı olarak Cumhuriyet gazetesinde yayınlanan reklamlar sırasıyla Sözcü, Evrensel ve Hürriyet Gazetelerinde de yer almıştır.

\section{1 Kasım 2015 Seçimlerinde Ulusal Gazetelerde CHP Seçim Kampanyası}

1 Kasım Seçimleri kampanya sürecinde CHP'nin Cumhuriyet Gazetesinde 9, Evrensel ve Yeni Çă̆ Gazetelerinde 2, Hürriyet Gazetesinde 3, Sözcü Gazetesinde ise 5 reklamla toplamda 21 reklamı gazetelerde yer almıștır. 7 Haziran Seçimlerinde olduğu gibi Sabah ve Yeni Şafak Gazetelerinde CHP'nin reklamının yer almadığı görülmüştür.

İlanların içeriklerine bakıldığında "Biz Varız Yaparız" ve "Önce Türkiye" sloganlarının kullanıldığı, her vatandaşın derdine derman olunacağı ifade edilerek hazırlanan ilanda CHP iktidarında ilk yüz gün ve ilk bir yıl gerçekleştirilecek vaatler birlikte sunulmaktadır. CHP İktidarında ilk yüz günde yapılacaklar; emeklilere Ramazan ve Kurban Bayramlarında birer maaş ikramiye verileceği, Aile Sigortası Kanunun çıkarılacağı, kamuda taşeron işçiliğe son verilerek mevcut taşeron işçilerin kadroya alınacağı, kredi kartı ve tüketici kredilerindeki faiz borçlarının yüzde sekseninin silineceği, siyasi ahlak yasası çıkarılacağı, TBMM'de Kesin Hesap Komisyonunun kurulacağı, Passolig uygulamasının kaldırılacağı ve üniversite mezunlarının okurken aldıkları kredilerinin ödemesinin iş buluncaya kadar erteleneceği vaatleri sıralanmaktadır. 
A.H.Zabun 7 Haziran ve 1 Kasım 2015 Genel Secimleri Bağlamında...

CHP İktidarında ilk bir yılda yapılacak olanlar; çiftçiye mazotun 1,80 TL'den verilmeye başlanacağı, asgari ücretin vergisi kaldırılarak net 1500 TL'ye çıkarılacağı, esnafın emekli aylığından kesilen sosyal güvenlik destekleme priminin kaldırılacağı, yüzde onluk seçim barajının kaldırılacağı, bir yıl içerisinde öğrencilerin yurt sorunun çözüleceği, teşvik sisteminin değiştirilerek, katma değeri yüksek üretimi özendiren sektörel teşvik politikasının uygulanacağ 1 , vergi ve sigorta prim borcu olmayan KOBİ'lerin ödedikleri vergi ve sigorta primi kadar sıfır faizli krediye erişimini sağlayacak yasal düzenleme yapılacağ 1 ve vahidi fiyat uygulamasına son verilerek orman köylüsünün sigortalı işçi olarak çalıştırılacağ 1 ve emeklilik hakkı elde edeceği vaatleri sıralanmıştır.

7 Haziran genel seçim kampanyasında seçim vaatlerinde her başlık ayrı bir ilana konu olmuşken, CHP 1 Kasım seçim sürecinde vaatlerini tek bir ilanla seçmene sunmayı tercih etmiştir. Ayrıca içerikte vaat olmayan birlik-beraberlik mesaj1 veren ve seçmene seçime katılarak CHP'ye oy verme çağrısı içeriği olan iki ayrı ilan daha yazılı basında kullanılmıştır.

CHP lideri Kemal Kılıçdaroğlu'nun fotoğrafının kullanıldığı siyah fon içerisinde "Benim bu bitmeyen kavgayla derdim var. Benim bu bitmeyen fakirlikle derdim var. Ve ben yalnız değilim...Huzur ve refah isteyenler çoğunluk bu ülkede." mesajı ve "Biz varız. Milyonlarız. Birlikteysek, yaparız" sloganının kullanıldığı kampanya materyali ile "Bu Seçime damganı Vur" başlığı, "Güvenliğimizi zaafa uğratana değil, zor zamanlarda bile uzlaşma arayanlara EVET de", "Yıllardır iktidarda yorulana değil, bu görev için heyecanla çalışana EVET de", "Umudu kesip seçim günü evde oturma, değişime EVET de" mesajları ve "CHP'ye EVET de" sloganını içeren kampanya materyali kullanılmıştır.

Farklı gazetelere verilen ilanların çeşitliliği açısından incelendiğinde CHP'nin seçmen karşısına 7 Haziran Kampanya sürecinde 13 farklı mesajla çıktı̆̆ 1 görülürken 1 Kasım seçim sürecinde 3 farklı görselle seçmene ulaşmaya çalıştı̆̆ 1 tespit edilmiştir. Bu planlamada bütçe kısıtlılığının etkisi olabileceği gibi tüm seçmen gruplarını tek bir ilanla yakalama ve etkileme stratejisinin amaçlandığı düşünülebilir. Ancak tekrarlanan seçimde mesaj yoğunluğun azaldığı görülmektedir. 


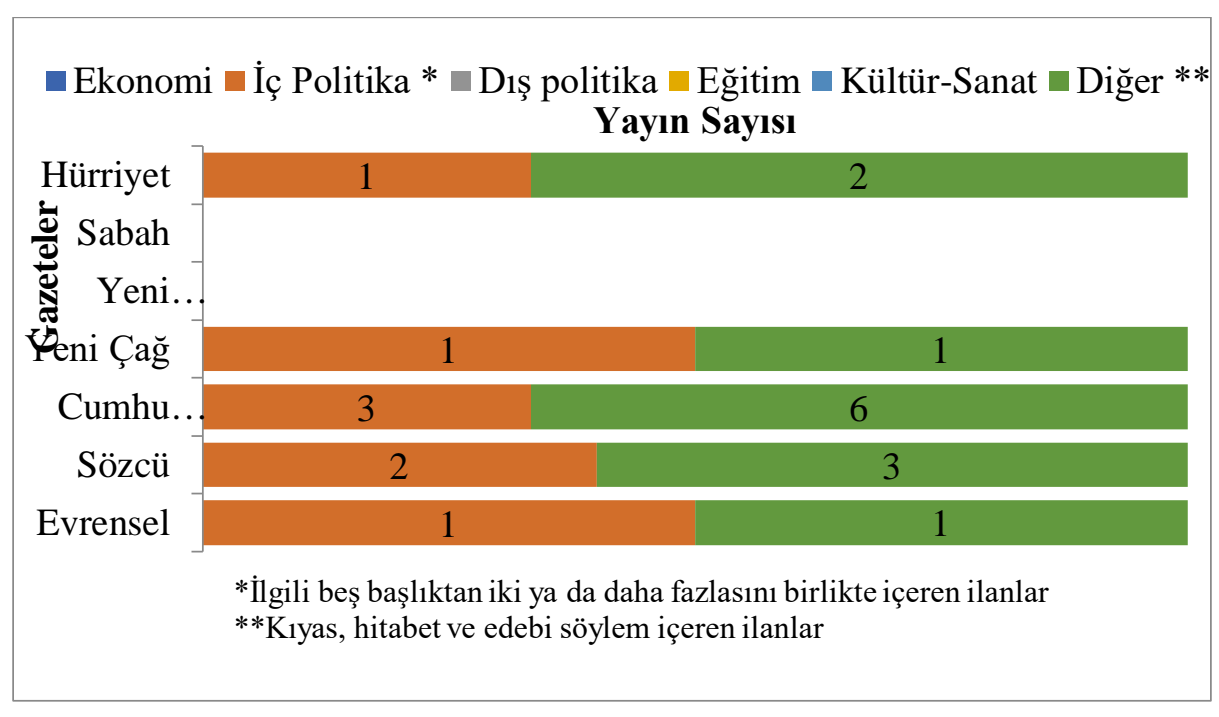

Şekil 3. İleti Konuları Başlığında Kasım 2015 Seçimlerinde CHP'nin Reklam Konu Dağılımı

Kasım 2015 Genel Seçimlerinde CHP reklamlarının gazetelere göre dağglımına bakıldığında; \% 43 ve \% 24'lük oranla Cumhuriyet ve Sözcü Gazetelerine daha fazla reklamın verildiği, Haziran 2015 seçimlerinde olduğu gibi Yeni Çağ, Hürriyet ve Evrensel Gazetelerinin de farklı toplumsal kesimlere ulaşabilmek amacıyla kullanıldığı görülmektedir.

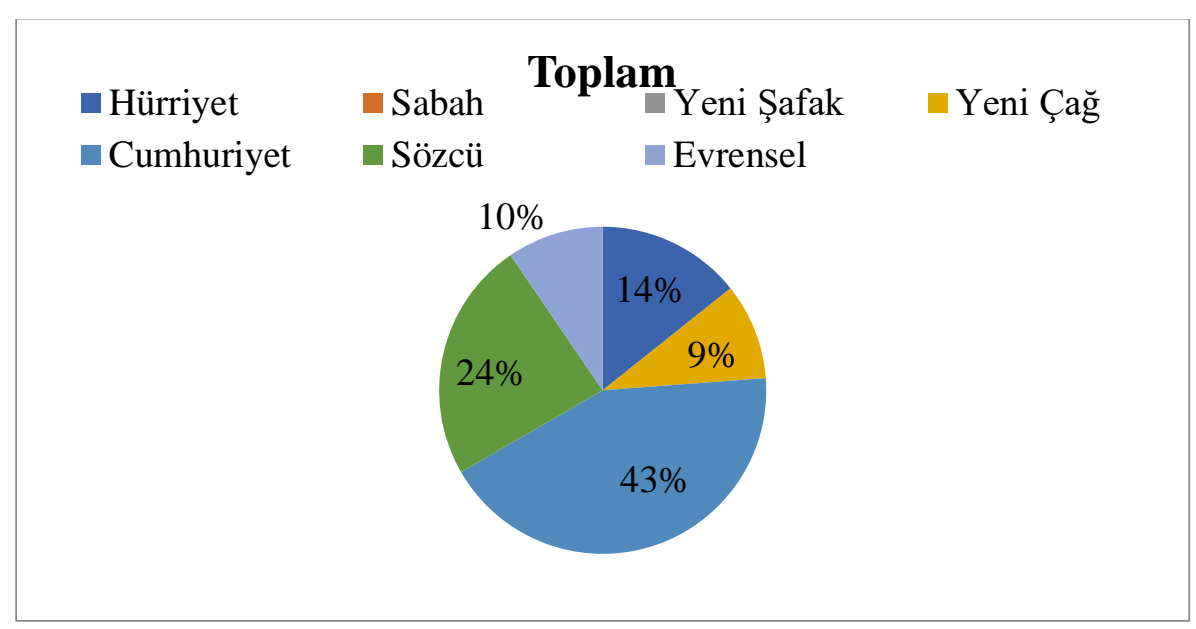

Şekil 4. Kasım 2015 Seçimlerinde CHP Reklamlarının Gazetelere Göre Dağılımı 
A.H.Zabun 7 Haziran ve 1 Kasım 2015 Genel Secimleri Bağlamında...

\section{Karşılaştırma ve Sonuç}

7 Haziran 2015 genel seçimleri kampanya sürecinde CHP’nin incelenen yedi basılı medya organının beşinde reklam verdiği görülmektedir. Bu gazetelerde yayınlanan reklamlar, reklam konu dağılımı açısından değerlendirildiğinde ekonomi ağırlıklı bir tabloyla karşılaşılmaktadır. Seçim kampanyaları seçmen talepleri ya da beklentileri doğrultusunda şekillendiğinden bu durum seçmenin ekonomik beklentilerinin ön planda olduğunun bir göstergesidir. 87 reklamın 56'sının ekonomi içerikli olması 7 Haziran 2015 genel seçim kampanyasının neredeyse tamamen ekonomi merkezli bir kampanya olarak tasarlandığ 1 bulgusunu ortaya koymaktadır. İç politika alanına giren mesajların da ekonomi konu başlığı yanında belirli bir yoğunlukta olması etkili bir seçim kampanyası çalışması olarak değerlendirilebilir.

Seçilen medya organlarının toplumsal karşılıkları bağlamında bir değerlendirme yapıldığında farklı seçmen kitlelerine seslenen medyalarla ana akım medyaların bir arada kullanılmaya çalışıldığı ortaya çıkmaktadır. Sabah ve Yeni Şafak Gazetelerinin tercih nedeni olup olmadıkları ya da yayın politikası gereği olumsuz cevap alınarak mı kullanılmadıkları konusunda bir veriye sahip olunamaması nedeniyle bir saptama yapılamamaktadır. Ancak Evrensel ve Yeni Çağ gibi iki farklı mecranın kullanılmış olması CHP'nin seçim kampanyasındaki mesajlarını tüm toplumsal kesimlere ulaştırma çabası olarak ifade edilebilir.

Reklamların içeriklerinde sorunları dolayısıyla seslenilen öğrenci, öğretmen, asgari ücretli, çiftçi, emekli, esnaf ve KOBİ vurgularıyla seçmenlerin önemli bir kısmına hitap edildiği bir başka bulgu olarak karşımıza çıkmaktadır. İktidarı ya da tek başına iktidarı belirleyecek potansiyele sahip bir toplumsal kitlenin kampanyada doğrudan mesajlarla muhatap alınması, sorun ve çözüm önerilerinin kısa mesajlarla sunulması kampanyanın etkililiğini artıran bir strateji olarak görülmektedir.

1 Kasım 2015 genel seçim kampanya sürecinin zaman açısından sınırlılığı ve ekonomik olanaklar da göz önünde bulundurularak mesajların tek bir reklamla verilmesi ve mesaj sıklığının azalması ortaya çıkan bir başka bulgudur. 7 Haziran 2015 genel seçimlerinde kullanılan medyalar yine kullanılmış ancak reklam konu dağılımı iç politika ve diğer başlı̆̆ altında sınırlanmıştır. Toplamda üç farklı (biri iç politika, ikisi diğer başlıkları altında) reklam ve 21 yayınlanma ile yine 7 Haziran seçimlerine göre daha az reklam ve daha kısıtlı bir yayın söz konusudur. $\mathrm{Bu}$ bağlamda kısa, sade ve yinelenen mesaj stratejisinin 1 Kasım 2015 genel seçimlerinde terkedildiği ifade edilebilir.

7 Haziran ve 1 Kasım 2015 genel seçimleri reklam konu dağılımı ve mesaj sıklığı açısından karşılaştırıldığında ekonomi odaklı ve çok sayıda mesaj yayınlama çerçeveli bir kampanya stratejisinden iç politika odaklı ve daha az 
sayıda mesaj yayınlama gibi bir stratejiye dönüştügü görülmektedir. Çalışmanın giriş bölümünde incelenen genel seçimlerde kampanya stratejisini uzun ve çözümlemeye ihtiyaç duyan konu ve mesaj stratejisinden ekonomi içerikli kısa ve net mesajlara dönüştüren Ak Parti'nin oylarını artırarak tek başına iktidar olduğu ifade edilmişti. $\mathrm{Bu}$ bağlamda seçim kampanyası organizasyonunun seçmenin beklentileri doğrultusunda farklı medyalarda kısa ve yinelenen mesajlarla gerçekleştirilmesinin etkili olduğu ifade edilebilir.

\section{KAYNAKÇA}

Ayata Güneş, Ayșe (2010), CHP (Örgüt ve İdeoloji), (Çev. Belkıs Tarhan, Nüvit Tarhan), Gündoğan Yayınları, İstanbul.

Aybek, Şahin (2009), CHP Tarihi, Maya Akademi Yayınları, Ankara.

Bila, Hikmet (2008), CHP: 1919-2009, Doğan Kitap, İstanbul.

Karlı, İhsan (2009), 1946-2007 Türk Basınında Milletvekili Genel Seçimleri, (Yayımlanmamış doktora tezi), Marmara Üniversitesi, Sosyal Bilimler Enstitüsü, İstanbul.

Öz, Esat (1992) Tek Parti Yönetimi ve Siyasal Katılım, Gündoğan Yayınları, Ankara.

Turan, Şerafettin (2000), Kökeni Ulusal Direnişe Dayanan Bir Devrim Partisi Cumhuriyet Halk Partisi, Tüses Yayınları, İstanbul.

Uyar, Hakkı (2012), Tek Parti Dönemi ve Cumhuriyet Halk Partisi, Boyut Yayınları, İstanbul. 